\title{
UPTAKE OF HEAVY METALS BY VEGETABLES GROWING ON SEWAGE SLUDGE
}

Valdas PAULAUSKAS, Department of Environment and Ecology, Agriculture Academy, Vytautas Magnus University, K. Donelaičio g. 58, 44248 Kaunas Lithuania, valdas.paulauskas@vdu.lt (corresponding author)

Alfreda KASIULIENE், Department of Civil, Environmental and Natural Resources Engineering, Luleå University of Technology, Sweden. Contacts: SE-971 87 Luleå, Sweden, alfreda.kasiuliene@gmail.com

Concentrations of the investigated heavy metals in the representative samples of vegetable growing media differed significantly - the highest concentrations were in the root zone of pumpkin, and the lowest - in the root zone of tomato. Only cadmium exhibited higher concentrations in the root zone of pumpkin and zucchini exceeding maximum permissible limits according to LAND 20-2001. Concentrations of all other metals in the root zone of the investigated vegetables were below limit values valid for the 1st category sewage sludge. Mean concentrations of nitrogen, phosphorus and potassium in the root zone was quite different for the three selected plant species, but comparably high bioavailable concentrations of the primary plant nutrients showed potential for this sludge to be used in agriculture or forestry. Concentrations of $\mathrm{Cr}$, $\mathrm{Ni}$ and $\mathrm{Pb}$ in the sewage sludge were far below the critical range, while $\mathrm{Cd}, \mathrm{Zn}$ and $\mathrm{Cu}$ concentrations were within the range or even above critical soil concentration values suggested in the reviewed literature. While average heavy metal concentrations in different parts of the investigated vegetables (pumpkin, zucchini and tomato) were much lower than the suggested critical ones, and was within the range $(\mathrm{Cu}, \mathrm{Zn}, \mathrm{Cr}$ and $\mathrm{Ni}$ ) or even lower $(\mathrm{Cd}$ and $\mathrm{Pb}$ ) than normal $\mathrm{HM}$ level in plants. Concentration of all of the investigated heavy metals was significantly lower in vegetable fruits than in the roots and no metal accumulation in the vegetable biomass (roots as well as aboveground parts) was observed - all accumulation coefficients were below unity.

Keywords: heavy metals, uptake, sewage sludge, bioaccumulation, vegetables, pumpkin, zucchini, tomato

\section{INTRODUCTION}

The philosophy of so called beneficial use increased the tendency to favour land application over other means of disposal of industrial waste that have characteristics potentially valuable for agriculture. But on-land disposal of waste materials containing heavy metals (HM) can give rise to accumulation of these potentially toxic elements in the topsoil, following adverse effects on plant growth and crop quality. Since heavy metals are non-biodegradable, the contamination persists long time after heavy metal containing contaminants have entered the soil. Such pollution is even more dangerous given the fact, that plants are a first-hand bond between soil chemical composition and food chain (Khalid, S. et al., 2017; Bolan et al., 2014; Tchounwou et al., 2012).

As a rule, plants easily uptake heavy metals that are dissolved in the soil solutions in ionic or chelated chemical forms. The mobile HM fraction behaves like positive divalent ions and is controlled by dynamic equilibria between soil solid and liquid phases (Rajakaruna and Boyd, 2008). These are the main processes that can influence HM transition from insoluble to soluble fractions and vice versus: dissolution, sorption, complexation, precipitation, occlusion, diffusion (into minerals), binding by organic substances, absorption and sorption by microbiota (Zaidi et al., 2012; Kabata-Pendias, 2011; Zeng et al., 2011). Because of numerous factors influencing plant and soil physical relationship plants uptake HM at a different extent. Most plant species can exclude excess of bioavailable metals, especially of micronutrients, at their roots by binding them to organic acids or ligands and store them in vacuoles. Once HM compounds are locked in the vacuole of the root cell, their transport to the aboveground tissues is limited and interference with important physiological processes is weak. On the other hand, not all plants exclude heavy metals. Some plant species are tolerant to HM excess and accumulate bioavailable metals in the aboveground parts (Gall et al., 2015; Orsini et al., 2012).

Plants exhibit different sensitivity to heavy metal contamination (Fig. 1). Phytotoxicity level also depends upon individual metal and its compounds, also soil $\mathrm{pH}$ and redox potential that can strongly affect metal toxicity as they determine the chemical form in which metal will be present in the soil. For example, in slightly acidic soils ( $\mathrm{pH}$ 5.5-6.0) copper can be twice and Ni four times more toxic than Zn. Plants absorb HM from soil solution through the root system. Plant type, nature of soil, climatic conditions as well as agricultural practice influence the uptake of heavy metals. Intensive farming aimed at maximising crop yields may also affect HM uptake (heavy use of pesticides and chemical fertilizers, origin of agrochemicals). Waste disposal, like sewage sludge (SS), compost and solid or liquid manure on agricultural fields may also result in increased mobility and thus bioavailability of HM in soil (Peccia et al., 2015; Somasundaram et al., 2012; Radojević and Bashkin, 1999). As terrestrial plants are the first step of food chain, it is

Copyright (C) 2021 The Authors. Published by Vytautas Magnus University. This is an open-access article distributed under the terms of the Creative Commons Attribution License (CC BY 4.0), which permits unrestricted use, distribution, and reproduction in any medium, provided the original author and source are credited. 
important to have good knowledge about their capacity to accumulate toxic elements and ability to pass them on to animals and humans (Reeves et al., 2017; Nagajyoti et al., 2010).

\begin{tabular}{|c|c|c|c|}
\hline LOW & MODERATE & HIGH & RY HIGH \\
\hline $\begin{array}{l}\text { - Corn } \\
\text { - Sudan grass }\end{array}$ & $\begin{array}{l}\text { - Cucumber } \\
\text { - Flatpea } \\
\text { - Oat } \\
\text { - Orchard grass }\end{array}$ & $\begin{array}{l}\text { - Mustard } \\
\text { - Spinach } \\
\text { - Broccoli } \\
\text { - Tomato } \\
\text { - Alfalfa } \\
\text { - Soybean } \\
\text { - Timophy }\end{array}$ & $\begin{array}{l}\text { - Lettuce } \\
\text { - Carrot } \\
\text { - Turnip } \\
\text { - Peanut }\end{array}$ \\
\hline
\end{tabular}

Figure 1. Relative effect of heavy metal phytotoxicity on the selected crops (after Radojevic and Bashkin, 1999)

Aim of this study was to evaluate heavy metal concentration in the growing media as well as HM accumulation in different parts of some vegetable crops grown on municipal sewage sludge.

\section{RESEARCH METHODS}

Root, stem, leaf, fruit and seed samples of the three vegetable crop species (pumpkin "Big Max", zucchini "Ambassador F1" and tomato (unidentified)) were collected in October, 2015 at SS storage site in Ezerelis, Kaunas district, Lithuania. Sewage sludge (growing media) samples together with plant roots were taken using stainless-steel sampler. All aboveground plant material samples were sealed in plastic bags and transported to the laboratory where they were thoroughly washed with bidistilled water, dried at $60^{\circ} \mathrm{C}$ for 24 hours and finally either chopped or milled. Lead (Pb) and cadmium $(\mathrm{Cd})$ were detected with graphite furnace atomic absorption spectrometer following the standard LST EN 15550:2008. Chromium (Cr), copper (Cu), nickel (Ni) and zinc $(\mathrm{Zn})$ were determined by inductively coupled plasma atomic emission spectrometric (ICP-AES) analysis following the standard LST EN 15621:2012.

Samples of the growing media (SS) were taken at a root zone of the investigated plants. Joint soil samples of approximately $2 \mathrm{~kg}$ were pooled from 3-5 different spots; bigger roots and other debris were removed. After SS homogenization in the lab, subsamples of approximately $0.5 \mathrm{~kg}$ were dried until air-dry status. Cadmium, $\mathrm{Cu}$ and $\mathrm{Zn}$ were analysed with graphite furnace or flame AAS following ISO 11047:1998. For chromium, Ni and Pb - the ISO 22036:2008 standard was used. Sludge $\mathrm{pH}$ was determined with ion-meter in 1 molar potassium chloride suspension using standard method (LST ISO 10390:2005). Mineral nitrogen (N) in the sludge was analysed applying spectrometric flow method. Water soluble phosphorus (expressed as $\mathrm{P}_{2} \mathrm{O}_{5}$ ) and potassium (expressed as $\mathrm{K}_{2} \mathrm{O}$ ) were detected using Egner-Reihem Domingo method.

All instrumental analyses were performed in triplicates. Significance level between the means was calculated using analysis of variance (ANOVA) tool pack for a $t$-test (two sample analysis assuming unequal variances) when $\mathrm{p}_{\mathrm{p}}<0.05$. Bioaccumulation factor (BCF) was calculated as a ratio of the total concentration of an element in the roots to its concentration in the growing media. Translocation factor (TF) was calculated as a ratio of the total concentration of an element in the aboveground parts of the plant to the concentration in the roots.

\section{RESEARCH RESULTS}

Heavy metal content in the growing media of the selected vegetable crops is presented in Table 1. According to national normative document (LAND 20-2001) SS regarding HM content is classified into 3 categories. Concentrations for the $2^{\text {nd }}$ and $3^{\text {rd }}$ category starting from 2022 will be much lower than the existing. Only sludge of $1^{\text {st }}$ category can be used directly in agriculture or during land reclamation. Maximum permissible concentrations (MPC) depending upon the category are presented in Table 1.

Table 1. Heavy metal concentrations in the growing media of each vegetable compared to MPCs applied for different sludge categories after LAND 20-2001

\begin{tabular}{l|c|c|c|c|c|c}
\multirow{2}{*}{ Analytes } & \multicolumn{2}{|c|}{ Concentration in root zone, ppm dry weight } & \multicolumn{3}{c}{ MPC for different SS categories, ppm dry weight } \\
\cline { 2 - 7 } & pumpkin & zucchini & tomato & $1^{\text {st }}$ & $2^{\text {nd }}$ & $3^{\text {rd }}$ \\
\hline \hline $\mathrm{Pb}$ (lead) & 45 & 24 & 10 & $\leq 140$ & $140-750$ & $>750\left(150^{*}\right)$ \\
$\mathrm{Cd}$ (cadmium) & $\mathbf{1 . 9}$ & $\mathbf{1 . 8}$ & 0.5 & $\leq 1.5$ & $1.6-20$ & $>20(5)$ \\
$\mathrm{Cr}$ (chromium) & 48 & 41 & 21 & $\leq 140$ & $141-400$ & $>400(170)$ \\
\hline $\mathrm{Ni}$ (nickel) & 13 & 15 & 11 & $\leq 50$ & $51-300$ & $>300(70)$ \\
$\mathrm{Cu}$ (copper) & 128 & 65 & 55 & $\leq 300$ & $301-1000$ & $>1000(500)$ \\
$\mathrm{Zn}$ (zinc) & 588 & 443 & 145 & $\leq 800$ & $801-2500$ & $>2500(1500)$
\end{tabular}

*new limit values to be valid from 2022 
Concentrations of HM in the representative samples of vegetable growing media differed significantly (Table 1) - the highest HM concentrations were in the root zone of pumpkin, and the lowest - in the root zone of tomato. The only one metal - cadmium exhibited higher concentrations exceeding limit values in the root zone of pumpkin and zucchini according to LAND 20-2001. Concentrations of all other metals in the root zone of the investigated vegetables were below 1 st category MPC.

Plant-metal interactions may be beneficial, have no effect or be harmful depending on metal species and concentrations (Chibuike et al., 2014). Normal ranges of HM concentrations in plants are given in Table 2 (after Alloway et al., 2013) as well as critical concentrations for the plants. These concentrations are likely to be fatal or cause a significant yield reduction. Table 2 also presents critical HM concentrations in the soil as well as HM concentrations in the root zone of the investigated growing media (the last column).

Table 2. Normal range of heavy metals in crops and critical concentrations both in plants and soils (after Alloway et al., 2013) compared with HM concentrations in the investigated sewage sludge

\begin{tabular}{l|c|c|c|c|c} 
Heavy metal & $\begin{array}{c}\text { Normal range } \\
\text { in crops, } \\
\text { ppm }\end{array}$ & $\begin{array}{c}\text { Critical concentration } \\
\text { in plants above which } \\
\text { toxicity is likely, } \\
\text { ppm }\end{array}$ & $\begin{array}{c}\text { Critical concentration in } \\
\text { plants, likely to cause } \\
10 \% \text { yield reduction, } \\
\text { ppm }\end{array}$ & $\begin{array}{c}\text { Critical } \\
\text { concentration } \\
\text { in soil, } \\
\text { ppm }\end{array}$ & $\begin{array}{c}\text { Concentration in } \\
\text { the investigated } \\
\text { growing media, } \\
\text { ppm }\end{array}$ \\
\hline \hline $\mathrm{Mn}$ (manganese) & $20-1000$ & $300-500$ & $100-7000$ & $1500-3000$ & $-($ no data) \\
$\mathrm{Zn}$ (zinc) & $1-400$ & $100-400$ & $100-900$ & $70-400$ & $\mathbf{1 4 5 - 9 5 7}$ \\
$\mathrm{Cu}$ (copper) & $5-20$ & $20-100$ & $5-64$ & $60-125$ & $\mathbf{5 5 - 2 0 0}$ \\
\hline $\mathrm{Ni}$ (nickel) & $0.02-5$ & $10-100$ & $8-220$ & 100 & $\mathbf{1 1 . 0 - 1 7 . 2}$ \\
$\mathrm{Cr}$ (chromium) & $0.03-14$ & $5-30$ & $2-18$ & $10-75$ & $\mathbf{3 . 6 - 1 0 . 5}$ \\
$\mathrm{Co}$ (cobalt) & $0.02-1$ & $15-50$ & $4-40$ & $25-50$ & - \\
\hline $\mathrm{Pb}$ (lead) & $0.2-20$ & $30-300$ & - & $3-400$ & $\mathbf{9 . 6 - 4 5 . 1}$ \\
$\mathrm{Cd}$ (cadmium) & $0.1-2.4$ & $3-5$ & $1-8$ & $0.3-5$ & $\mathbf{0 . 5 - 3 . 9}$
\end{tabular}

Chromium, $\mathrm{Ni}$ and $\mathrm{Pb}$ concentrations in the investigated sewage sludge were far below the critical range suggested by Alloway et al., 2013, while concentrations of $\mathrm{Cd}, \mathrm{Zn}$ and $\mathrm{Cu}$ were within the critical range or even above the provided limit heavy metal values in soil. Sewage sludge pH-values in the root zone were between 5.8-7.7; while mean concentrations of plant nutrients were quite different for the three selected vegetable crop species: $\mathrm{P}$ (soluble) concentration - 1347-9640 ppm; K (soluble) concentration - 172-1650 ppm; N (mineral) concentration - 218- 2918 ppm. Comparably high content of essential plant macronutrients $(\mathrm{N}, \mathrm{P}, \mathrm{K})$ showed potential for this sludge to be used in agriculture or forestry.

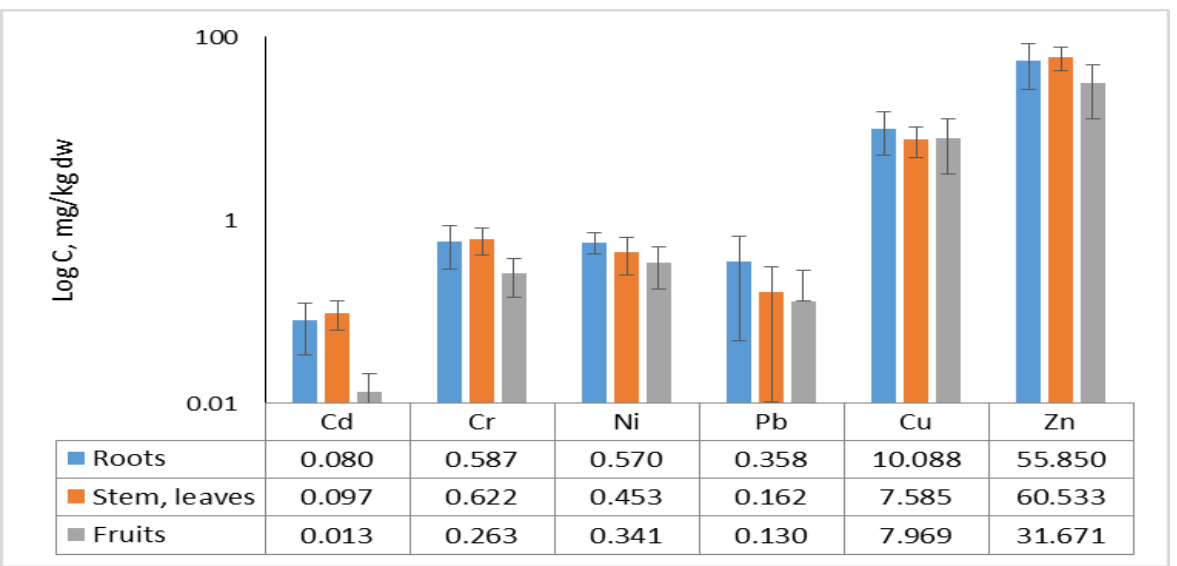

Figure 2. Average HM concentrations in different parts of vegetable crops grown on sewage sludge

While summarised HM concentrations (Fig. 2) in different parts of the investigated vegetable crops were much lower than the suggested critical ones (Alloway et al., 2013), and were within the range (for $\mathrm{Cu}, \mathrm{Zn}, \mathrm{Cr}$ and $\mathrm{Ni}$ ) or even lower $(\mathrm{Cd}$ and $\mathrm{Pb})$ than the normal $\mathrm{HM}$ level in plants (Table 1, Fig. 2). Moreover, concentration of all of the investigated HM was significantly lower in vegetable fruits than in the roots (Fig. 2). Finally, no evidence of heavy metal accumulation in the vegetable aboveground parts was observed - all accumulation coefficients were below unity.

\section{CONCLUSIONS}

- Concentrations of the investigated heavy metals in the representative samples of vegetable growing media differed significantly - the highest concentrations were in the root zone of pumpkin, and the lowest - in the root zone of tomato. Only 
cadmium exhibited higher concentrations in the root zone of pumpkin and zucchini exceeding maximum permissible limits according to LAND 20-2001. Concentrations of all other metals in the root zone of the investigated vegetables were below limit values valid for the 1st category sewage sludge.

- Mean concentrations of plant nutrients in the root zone was quite different for the three selected plant species: $\mathrm{P}$ (soluble) concentration - 1347-9640 ppm; K (soluble) concentration - 172-1650 ppm; N (mineral) concentration - 2182918 ppm. Comparably high bioavailable concentrations of essential plant macronutrients (N, P, K) showed potential for this sludge to be used in agriculture or forestry.

- Chromium, $\mathrm{Ni}$ and $\mathrm{Pb}$ concentrations in the investigated sewage sludge were far below the critical range suggested in the reviewed literature, while concentrations of $\mathrm{Cd}, \mathrm{Zn}$ and $\mathrm{Cu}$ were within the range or even above the limit heavy metal concentration values in soils.

- Summarised heavy metal concentrations in different parts of the investigated vegetable crops were much lower than the suggested critical ones, and were within the range (for $\mathrm{Cu}, \mathrm{Zn}, \mathrm{Cr}$ and $\mathrm{Ni}$ ) or even lower (for $\mathrm{Cd}$ and $\mathrm{Pb}$ ) than the normal heavy metal concentrations in plants. Concentration of all of the investigated metals was significantly lower in vegetable fruits than in the roots and no evidence of heavy metal accumulation in the vegetable aboveground parts was observed - all accumulation coefficients were below unity.

\section{REFERENCES}

1. Alloway B. J. (ed.). 2013. Heavy metals in soils. Trace metals and metalloids in soils and their bioavailability. Dordrecht: Springer Science + Business Media. https://doi.org/10.1007/978-94-007-4470-7

2. Bolan N., Kunhikrishnan A., Thangarajan R., Kumpiene J., Park J., Makino T., Kirkham M. B., Scheckel K. 2014. Remediation of heavy metal(loid) contaminated soils - To mobilize or to immobilize? Journal of Hazardous Materials, Vol. 266, pp. 141-166. https://doi.org/10.1016/j.jhazmat.2013.12.018

3. Chibuike G., U., Obiora S., C. 2014. Heavy metal polluted soils: effect on plants and bioremediation methods. Applied and Environmental Soil Science, Vol. 2014, pp. 1-12. https://doi.org/10.1155/2014/752708

4. Gall J. E., Boyd R. S., Rajakaruna N. 2015. Transfer of heavy metals through terrestrial food webs: a review. Environmental Monitoring and Assessment, Vol. 187, pp. 201-222. https://doi.org/10.1007/s10661-015-4436-3

5. Kabata-Pendias A. 2011. Trace elements in soils and plants. Boca Raton, Taylor \& Francis Group. https://doi.org/10.1201/b10158

6. Khalid S., Shahid M., Niazi N. K., Murtaza B., Bibi I., Dumat C. 2017. A comparison of technologies for remediation of heavy metal contaminated soils. Journal of Geochemical Exploration, Vol. 182, pp. $247-268$. https://doi.org/10.1016/i.gexplo.2016.11.021

7. LAND 20-2001. Rules for using sewage sludge in agricultural and land reclamation, No 61-2196. In Lithuanian. Latest access 20210929 at https://e-seimas.lrs.lt/portal/legalAct/lt/TAD/TAIS.143603/asr

8. Marmiroli M., Imperiale D., Maestri E., Marmiroli N. 2004. The response of Populus spp. to cadmium stress: Chemical, morphological and proteomics study. Chemosphere, Vol. 93, pp. 1333-1344. https://doi.org/10.1016/j.chemosphere.2013.07.065

9. Nagajyoti P. C., Lee K. D., Sreekanth T. V. M. 2010. Heavy metals, occurrence and toxicity for plants: a review. Environmental Chemistry Letters, Vol. 8, pp. 199-216. https://doi.org/10.1007/s10311-010-0297-8

10. Peccia J., Westerhoff P. 2015. We should expect more out of our sewage sludge. Environmental Science and Technology, Vol. 49, pp. 8271-8276. https://doi.org/10.1021/acs.est.5b01931

11. Radojević M., Bashkin V. N. 1999. Practical environmental analysis. Cambridge: The Royal Society OF Chemistry.

12. Rajakaruna N., Boyd R. S. Edaphic factor. Jorgensen, S. E, Fath, E. D. (eds) (2008). General ecology: encyclopaedia of ecology. Amsterdam: Elsevier Science, pp. 1201-1207. https://doi.org/10.1016/B978-008045405-4.00484-5

13. Reeves R. D. M. Baker A. J., Jaffré T., Erskine P. D., Echevarria G., Van der Ent A. 2017. A global database for plants that hyperaccumulate metal and metalloid trace elements. New Phytologist, vol. 218, pp. 407-411. https://doi.org/10.1111/nph.14907

14. Somasundaram J., Krishnasamy R., Savithri P., Mahimairaja S., Kumar B. S., Sivasubramanium K., Kumar V. A., Poongothai S., Coumar M. V., Behera S. K. 2012. Accumulation of few heavy metals in sewage sludges, soils and plants of Coimbatore, Tamil Nadu (India). Journal of Environmental Science \& Engineering, Vol. 54, pp. 27-42.

15. Tchounwou P. B., Yedjou C. G., Patlolla A. K., Sutton D. J. 2012. Heavy metals toxicity and the environment. Molecular, Clinical and Environmental Toxicology, Vol. 101, pp. 133-164. https://doi.org/10.1007/978-3-7643-8340-4_6

16. Zaidi A., Wani P. A., Khan M. S. (eds). 2012. Toxicity of heavy metals to legumes and bioremediation. Verlag Wien: Springer. https://doi.org/10.1007/978-3-7091-0730-0

17. Zeng F., Ali S., Zhang H., Ouyang Y., Qiu B., Wu F., Zhang G. 2011. The influence of pH and organic matter content in paddy soil on heavy metal availability and their uptake by rice plants. Environmental Pollution, Vol. 159, pp. 84-91. https://doi.org/10.1016/j.envpol.2010.09.019 